Georgetown University Institutional Repository http://www.library.georgetown.edu/digitalgeorgetown

Pireddu, Nicoletta. "A Moroccan Tale of an Outlandish Europe: Ben Jelloun's Departures for a Double Exile," Research in African Literatures, 40 (3), Fall 2009: 16-36. doi: $\underline{10.1353 / \text { ral.0.0180 }}$

Collection Permanent Link: http://hdl.handle.net/10822/559394

(C) 2009 Indiana University Press

This material is made available online with the permission of the author, and in accordance with publisher policies. No further reproduction or distribution of this copy is permitted by electronic transmission or any other means. 


\title{
A Moroccan Tale of an Outlandish Europe: Ben Jelloun's Departures for a Double Exile
}

\author{
NICOLETTA PIREDDU \\ Georgetown University \\ pireddun@georgetown.edu
}

\begin{abstract}
By exploring the relations between Morocco and Spain, Tahar Ben Jelloun's novel Partir provides a critical stance on migration and intercultural exchanges between Africa and Europe that transcends a unilateral indictment of European community-building policies and at the same time refrains from a heroization of the migrant plight as much as from the paternalizing approach it often disguises. Through what it defines as the "migrant bovarysm" in Partir, this article discusses Ben Jelloun's ambivalent position on issues of exile and hospitality between Africa and Europe highlighting the joint (albeit different) responsibilities of the two continents. The idealizations and prejudices emerging from both Mediterranean shores confine the novel's would-be Europeans to a liminal, spectral condition that ultimately alienates them from their homeland as much as from their receiving culture. Partir hence questions ethnic policies on a global scale and the liberating prospect of cultural hybridity as creolization beyond borders, by depicting the Mediterranean at once as threshold and bulwark between cultures
\end{abstract}

To Professor Giovanni Bonu and his Euro-Mediterranean island

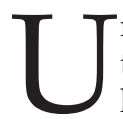

nder the title Mediterranean Europe, a trendy Lonely Planet guide promises to accompany travelers on a "multi-country" journey through the bright hues and the enthralling lifestyle of what it presents as the lands of sun, sea, and gastronomic delights. Made to embody at once the irresistible lure of the Mediterranean and the heritage of the Old Continent, the political vicissitudes, cultural

RESEARCH IN AFRICAN LITERATURES, Vol. 40, No. 3 (Fall 2009). (c) 2009 
legacies, and geographical features of diverse nations such as Spain, Bosnia, Malta, and Morocco blend unproblematically in the bold collocation of the title.

Yet, once we shift from popular to scholarly culture, we are confronted with far less lighthearted approaches that question the hypothesis of a monolithic Mediterranean Europe by calling attention to the complex geopolitical scenarios that separate the shores of the Mare Nostrum. For instance, literary and cultural historian Predrag Matvejević highlights the basin's troubling connections to its Northern and Southern continents, arguing that it is not even possible to consider the Mediterranean a single sea (Méditerranée 25) without accounting for the conflicts and lacerations in "meeting points" like Palestine, the Maghreb, or the Balkans - the very destinations that the Lonely Planet guide connects without asking, unlike Matvejević, whether a culture of the Mediterranean exists other than in our imaginary (33) and whether it can be defined so easily as European. The European Union, Matvejević claims, was built without taking into account the Mediterranean "cradle" of Europe, hence deepening the North-South divide. The sea itself increasingly resembles a frontier that, stretching from East to West, separates Europe from Africa and the Middle East and creates manifold Mediterranean cultures with similarities and differences that are neither absolute nor constant (34).

Matvejević's so-called "vision différenciée" 'differentiated perspective' (35) of this inner sea-namely, that of the Mediterranean at once as threshold and bulwark between cultures-provides an effective framework for the tensions on matters of immigration to Europe and on the political, cultural, and religious clashes they entail in that geographical space. Liminal and plural, the Mediterranean is indeed the primary location where the two polarized definitions of the Old Continent confront and question each other: "fortress Europe," depicting the European Union's reluctance to lower its drawbridge to extracommunitarian asylum seekers, and "Eurabia," summoning the prospect of an Islamization of Europe from the Southern and Eastern Mediterranean (see Ferguson).

Among the contributions to the timely issue of Europe's controversial identity in relation to its neighboring continents, The Force of Reason by Italian writer Oriana Fallaci offers one of the most ferocious pronouncements against the Mediterraneanization of "a Europe which has become Eurabia, which welcomes and favors the enemy, which even grants him the vote (267), while a great many postcolonial and migrant authors connected to various areas of the Mediterranean basin-from Driss Chraïbi to Simon Njami and Emin Sevgi Özdamar, among many others-reframe identity through the experience of mobility, exile, and diaspora, to undermine the national (if not nationalist) ideology still governing much discourse on European frontiers, and to resist their exclusion.

However, although numerous novels narrate stories of migration towards individual European nations, mostly connecting former colonizers and colonized, or, conversely, engaging with ethnic politics on a global scale, very few have focused on the specifically European question at stake or on the complexity of Euro-Mediterranean relations at large. The most recent novel by Tahar Ben Jelloun, Partir, occupies a singular space in this framework. It is the story of a Moroccan brother and sister who share with many other characters the desire to leave their families and country and cross the Strait of Gibraltar in search of a better life. The fulfillment of their dream comes at the cost of compromises and sacrifices that 
culminate with the protagonists' physical and emotional annihilation. Through an exploration of the relations between Morocco and Spain, Partir provides a critical stance on migration and intercultural exchanges between Africa and Europe that transcends a unilateral indictment of European community-building policies and at the same time refrains from a heroization of the migrant plight as much as from the paternalizing approach it often disguises.

Much like the differentiated perspective urged by Matvejević on the Mediterranean basin, Ben Jelloun hence problematizes also the liberating prospect of cultural hybridity as universal creolization beyond borders (as in Glissant or Gnisci), while through ambivalence and liminality he offers a nuanced position on issues of exile and hospitality between the African and the European continents, one that highlights the joint (albeit different) responsibilities of both the source country and the receiving culture.

\section{MIGRANT BOVARYSM}

On the first page of Partir, the narrator introduces readers to the driving force of the plot-the burning desire to quit one's homeland for good-by referring to a Cameroonian friend, Flaubert, who, as a sort of luck ritual, used to announce "j'arrive" ‘I arrive' upon departure and "nous sommes ensemble" 'we are together' when separating from someone (Partir 9). ${ }^{1}$ Such an unequivocal reference to the French literary giant in this character's name opens the novel with a powerful echo to the world of fiction that will fully disclose its effects in the final chapter. More subtly, however, the specific allusion to the author of Madame Bovary as a prelude to the story of malaise, daydreaming, and demise in Partir also sets up a connection between the ill-fated romantic fantasies of Flaubert's self-deluding Emma and the doomed reveries of Ben Jelloun's characters.

In what could be seen as a parody of the proverbially invisible and yet omnipotent Flaubert, who monitors his literary creatures and, with the critical power of his style, dissects their illusions as an impartial participant-observer, the opening scene of Partir zooms in on the Hafa Café in Tangier describing it as "un observatoire des rêves et de leurs conséquences" 'an observatory on their dreams and on their consequences' (11). Here the narrator's eye reads the obsession in the characters' thoughts and actions, namely, the yearning to quit Morocco and land in a Europe that promises the proverbial better life. No less stagnant than Emma Bovary's tedious provincial housewife life, the inertia that paralyzes this Moroccan town plagued by unemployment, corruption, and prostitution fosters compensatory daydreaming in which the longing for exile as a synonym for safety and success finds immediate fulfillment in artificial paradises and virtual travels. Amid clouds of kif smoke, the customers at the bar are lost "dans les limbes du haschisch et d'une rêverie de pacotille" 'in the limbo of hashish and of cheap reveries' (11) thanks to a "potion qui ouvre les portes du voyage" 'a potion that opens the doors to travel' (11), while on the horizon, across the sea and the winter clouds, the Spanish shores of Tarifa, the destination of their much longed-for, real trip, beckon to them, only fourteen miles away, as seductive as Ulysses's sirens precisely because of their closeness. The mirage of this almost tangible European Eldorado brings together young Moroccans and at the same time instigates one against the other in a mad and secretive competition. This pertains above all to 
Azel, unemployed despite his law degree and fixated on the prospect of leaping to the other side of the Mediterranean, which he relishes with tones worthy of the romances that captivated the Flaubertian Emma: "l'idée de prendre le large, d'enfourcher un cheval peint en vert et d'enjamber la mer du détroit, cette idée de devenir une ombre transparente, visible le jour seulement, une image voguant sur les flots à toute vitesse, ne le quitte plus" 'the idea of clearing off, of mounting a horse painted green and striding across the sea of the strait, this idea of becoming a transparent shadow, visible only during the day, an image floating on the waves at full speed, didn't leave him any more' (Partir 14). ${ }^{2}$

Since Jules de Gaultier's 1902 analysis of Emma's fancies of different existences and sublime impulses, "bovarysm" has come to designate a mental state that leads individuals to conceive of themselves as other than what they are (Gaultier 13), encompassing, more broadly, both the creativity that allows one to identify with ideal models through the exercise of imaginative powers, and any form of passionate and eccentric escapism. Although Flaubert himself fiercely criticizes the bourgeois conventions that Emma despises, he denounces the vain and excessive ambition of his character who belongs to that very world by targeting her unfulfilled desire. Emma's longing is doomed to failure precisely because it is nourished by the tendency to act according to preconceived ideas and illusions about herself and the world regardless of the gap between such desires and reality. Of the bovarysm of the pathetic Flaubertian character, a mythomaniac victim of her own romantic self-delusion rather than of destiny, there is more than it seems in Partir. Yet, Ben Jelloun's epigones of Emma receive early warnings about the danger of their fantasies. Disaster looms on their dreams even before their fulfillment. The salvaging sea in which they trust to become European is also the fiend that sends back ashore the bodies of those unlucky dreamers for whom the pilgrimage to the Promised Land across the Mediterranean turned into tragedy. Not accidentally, Moroccans have chosen the nickname "Toutia" to designate the sea, with which they evoke an ambivalent entity, "l'araignée tantôt dévoreuse de chair humaine, tantôt bienfaitrice" 'the spider sometimes avid of human flesh, and sometimes benevolent' (12), because it turns into a voice that warns them to postpone their voyage when the night is not good enough for departure.

These first pages purportedly devoted to the protagonists' quest for success through exile are already dotted with numerous intimations of death. As a morbid reminder of the demise that undermines the pervasive myth of departure, even the bees, "victimes de leur gourmandise" 'victims of their greed' (Partir 13), drown in the big glasses full of mint tea left untouched by the dreamy customers gazing fixedly at the horizon. Symbolic of the characters's own craving, the sad epilogue of those "petites bêtes noyées" 'drowned tiny creatures' (13) anticipates Azel's prefiguration of his own death by water, yet this bleak scenario is not enough to dissuade him and the other protagonists, yearning to quit their supposedly pitiless motherland.

The double-sided liaison between the opposite Mediterranean shores that these ambivalent images evoke is embodied by Al Afia, a ruthless trafficker devoted to manifold and suspicious dealings. The individual most Moroccans rely upon to cross the Mediterranean "frontière mobile" 'mobile frontier' (Partir 13), the sly resource person whose connections with and deep knowledge of European life seem to guarantee a successful epilogue to the saga of many desperate 
illegal immigrants, is also a mercenary, a treacherous Charon ${ }^{3}$ who, with his many nocturnal crossings and boat wrecks, has really transformed the Mediterranean into the cemetery recurring in Azel's nightmares. His alleged double marriage to a Spanish and a Moroccan woman, both living under the roof of his huge mansion on the sea, reinforces the bond between the two shores, making it look as natural as the geographical specularity and the phonetic affinity of Tangier and Tarifa. Yet Partir problematizes precisely the nature and the boundaries of that supposedly homogeneous Mediterranean Europe in which Morocco and Spain hold hands out to each other-as in Malika's idyllic dream of the bridge connecting them (123).

As Ben Jelloun lays bare conflicting emotional and social dynamics at work in the phenomenon of migration in general, he focuses on specific historical, political, and ethnic strifes between two adjacent but separate continents. In a novel that develops on the tightrope of ambivalence, the closeness and radical differences of the African and the European reality, which nourish the bovarysm of Ben Jelloun's characters, converge in two veritable "villes européennes" 'European towns' (147-48) on the Moroccan territory, the Spanish enclaves of Ceuta and Melilla. A problematic backdrop in the treatment of trans-Mediterranean migration, these hybrid areas cast a shadow over the prospect of greater border permeability and human mobility. Even without summoning the seductive and perfidious Toutia for a chance to cross the fluid frontier, Moroccans and Africans en masse can get a taste of the Old Continent on their own mainland, attracted by that peculiar and much contested land threshold between the European and the African Continent that has been defined as a "migration gateway to Europe" (Gold 120). While geographically African, Ceuta and Melilla are indeed not simply Spanish domains (having been in Spanish hands respectively since 1497 and 1668), but, precisely, European territories since Spain joined the European Community. As representatives of and regular participants in the political and economic activities of a wealthy European Union, but physically located in a developing continent and exhibiting their mixed heritage through architectural, ethnic, religious, and cultural heterogeneity, these paradoxical enclaves synthesize the complexity of inter-Mediterranean relations, from past sovereignty disputes between Morocco and Spain to Spain's more recent frictions with both the African and the European realities after becoming a country that not only exports its own citizens or favors transit towards other more sought-after European destinations, but also turns into a receiving nation itself (Gold xiii).

The Hafa Café in Ben Jelloun's Tangier is itself a border zone just like Ceuta and Melilla. It embodies the duplicity of those Spanish enclaves as protection areas sheltering the European dream from the challenges of its African surroundings and, at the same time, as presidios, what Ceuta and Melilla used to be called for their role as prisons keeping people away from Europe. Ironically, Al Alfia, the people-smuggler, effaces both sides of this double reality. The fire that echoes in his Arabic nickname (16) and that indeed burns the clandestines' documents to prevent them from being identified by authorities and repatriated in case of arrest already alludes to the double bereavement that awaits most migrants-the abandonment of their geographic and identitarian roots with no prospect of a new identity on the opposite shore of the Mediterranean. These mobile souls whose mental journey starts with an Edenic scenario that grants them participation in 
both the Moroccan and the Spanish reality, are soon estranged by both, in the Limbo (if not Hell) of a double exile. Destined to a nonlife, either because they encounter real death or because they are confined to a submerged existence with no hope of real integration, they hence exemplify one of those écarts d'identité that Azouz Begag analyzes in his discussion of the migrant plight. Begag's reflexions on departure as "arrachement" 'tearing off' (25) in his work on the Maghreb migration to France are equally pertinent to the South-North Mediterranean movement traced in Partir, where the characters struggle to introduce what Begag presents as a distance between themselves and their symbolic universe in an attempt to redefine themselves in another universe. Migration, Begag continues, "est bien plus qu'un simple déplacement physique d'un point à un autre dans un espace géographique. Elle ne se mesure pas en mètres mais en indices de changement. Il s'agit d'une rupture dans une continuité vivante et une greffe sur une autre continuité vivante" 'is far more than a simple physical displacement from one spot to another in a geographical space. It cannot be measured in meters but rather in change indexes. It is about a rupture in a living continuity and a graft onto another living continuity" (27). Within the framework of this traumatic rupture, Ben Jelloun's novel focuses in particular on the gap between the anticipation of success and the failure of the adventure of mobility. The migrants' bovarysm in Partir emerges precisely from this ironic double standard in the characters' identitarian recodification, which inscribes an endemic duplicity in the condition of the would-be Europeans of Tangier.

For instance, Azel is at the mercy of his "désir incontrôlable de partir" 'uncontrollable desire to leave' (Partir 27), "brûler les quatorze kilomètres qui nous séparent de l'Europe" 'to burn the fourteen kilometers that separate us from Europe' (36), although most of the other individuals possessed by the dream of a better life are now just corpses (like his cousin Noureddine) or even vanished into nothingness, as Mohamed-Larbi, probably recruited by Islamist cells. While strongly criticizing the practices of the Moroccan society that Azel means to quit, the narrator himself commiserates Azel's naivete and idealism-“Le pauvre! Il ne savait pas qu'il faisait fausse route" 'Poor guy! He didn't know he was on the wrong track' (32) - adding his voice to several other caveats like those from $\mathrm{Al}$ Alfia himself whose thriving new-slave trade with the Old Continent does not prevent him from claiming that "l'Europe ne veut pas de nous" 'Europe does not want to have anything to do with us' (25). But such warnings rapidly evaporate from the mind of Azel, who, like Emma Bovary plunged into her virtual tours of Paris (Madame Bovary, Première Partie, ch. 9), imagines himself already in Madrid comfortably settled on the terrace of one of the luxurious cafes of the Plaza Mayor, surrounded by friendly people (Partir 25).

To be sure, Abdeslam's aversion to the mania of Mediterranean crossings is the exception that confirms the rule in a novel where dreaming and departure are the keywords obsessively returning in many other characters' thoughts and conversations, from Siham's aspiration to a job in elderly caregiving in Europe, despite her previous failed crossings and arrests (36), to Malika's intention to leave Morocco after college-“Partir, n'importe où, (. . .) en Espagne, França, j’y habite déjà en rêve" 'Leaving, for no matter where, ... Spain, France, I am already living there in my dreams' (98) - and Lalla Zohra's vicarious reveries, in which, by setting foot in Europe, her daughter Kenza would find the ideal husband and her son 
Azel would become a physician or a highly ranked civil servant instead of longing to be nothing more than "une caisse de marchandise déposée dans un hangar en Europe, sur une terre de liberté et de prospérité" 'a crate of merchandise dropped in a hangar in Europe, on a land of freedom and prosperity (39). The Europe of Azel's fantasies is indeed a collage of the most obvious stereotypes, from its affluence and sophisticated tastes to its supposed strong family values that translate into compassionate individuals who even show their good heart towards animals (43). Yet, just as in the case of the gap that Flaubert creates between the internal romanticizing viewpoint of Emma's desires and the prosaic perspective of external reality, these very images are demystified by the contrasting scenario that the novel prefigures on the same pages, namely, the depiction of Spain as the first outpost of Fortress Europe, equipped with state-of-the-art surveillance technology to protect its borders from illegal infiltrations.

Azel ultimately succeeds in leaving Morocco in apparently more comfortable conditions than those reserved to the Europe-bound commercial cargos he envies. The encounter with Miguel, indeed, seems magically to fulfill what, in an ironic Freudian slip during a conversation with Siham, had emerged as the highest price he was ready to pay in order to make his dream come true on the other end of the Gibraltar Strait: getting married "avec un Espagnol ou un Français" 'with a Spanish or a French man' (Partir 37; emphasis added). Precisely thanks to the liaison with a Spanish man - the rich homosexual art dealer and viveur who rescues him from a police dragnet and ultimately gives him a chance to quit his country, Azel can board a plane with a regular visa application instead of risking an arrest or even his life on an illegal trafficker's boat, and finally lands on the European soil. Nevertheless, the intervention of this "homme providentiel" 'providential man' (66) who seems further to reduce the distance between the two Mediterranean shores by highlighting crucial analogies between the conditions of Morocco under the repressive regime of King Hassan and the plight of Franco's Spain, does not suffice to keep the dream alive. Ironically, indeed, it will be the very object of Azel's desire-Europe - that, once attained, will disclose its dangerous duplicity.

Precisely in the European Eldorado, bovarysm will show its devastating effects to all the migrants who, like Azel, believe in the chance to become what they wanted to, but could not be, in Morocco. Their adoptive land of freedom and prosperity, indeed, will promptly reveal the perverse underpinnings of the moral and legal norms of hospitality.

\section{UNNATURAL NATURALIZATIONS}

Ben Jelloun had already devoted attention to questions of immigration and hospitality in his essay Hospitalité française. In his introduction to the English edition, the "'reciprocal right to protection and shelter'" (1) involves more than simple tolerance or concern. Moroccan hospitality implies to "fill yourself with the other person" (2). Honored and humanized by the act of receiving the guest, the host is recognized as "someone capable of sharing ... of existing in relation to others" (2), of being enriched and completed by the stranger's alien nature by relinquishing the facile comfort of resemblance and of habit, and by opening up to the culture of difference and of the elsewhere. If these principles may already sound too idealistic to be applied consistently within the domestic sphere, with the shift from the ethics 
of interpersonal practices to the legal policies of the nation the scenario appears even more troublesome. What is the fate of human relationships when at stake is not just the encounter with the visitor at one's own home but, rather, a confrontation with the foreign immigrant on one's own domestic territory? Although they focus on the cultural contacts between North Africa and France, the reflections in Hospitalité française are equally pertinent to the more general interaction between the Mediterranean Southern and Northern shores sketched in Partir.

As an expatriate in Paris, Ben Jelloun with his essay bears witness to the predicament of his displaced compatriots and calls attention to the responsibility of France for often allowing its own tradition of hospitality to shade off into open hostility against North African workers at large, ${ }^{4}$ complying with the reception of foreigners and at the same time disregarding forms of racism targeting indistinctly first- and second-generation immigrants despite their different degrees of integration. For Ben Jelloun, "to feel French" means "both being critical and trying to open the doors of that citizenship wide enough to achieve a voluntary and successful intermingling" (Hospitality 17). Yet his enlightened perspective and his successful personal experience as a dual citizen and as a multicultural intellectual who ultimately made it to France do not overlook the widespread tendency to turn natural differences into social inequalities (61), which affects precisely the rough journey towards Europeanness undertaken by the protagonists of Partir.

Modifying the scenario of Ben Jelloun's essay, the novel focuses on a more exogenous and liminal reality in which immigration is not presented as a fait accompli but rather as an unstable process. The painful experience of North African "old timers" in Hospitalité française is at least redeemed by the recognition of later generations who now belong to a France "making no distinction between those who had to travel to get there and those who did not" (14), and who, as Ben Jelloun claims about himself, try "to strike a balance" (15) between their French and their Moroccan identities. Partir, however, lingers on characters who actually lose both their North African and their European identities, and who cannot even settle in the "no man's land" (Hospitality 14) of first-generation immigrants, sheltered by the fatalistic solitude of their exclusion by France. The idealized tones of Azel's letter to his country right before his departure for Spain synthesize well the Arab émigré's illusions of a temporary and profitable stay in an obliging, neighboring nation, ${ }^{5}$ which ultimately turns into a chronic condition of impermanence and alienation in part due to the émigré's own naïveté. The immigrant's idea of homeland, Ben Jelloun writes in his essay, "depends on the welcome he is given. . . He creates it as best he can, out of odds and ends or simply in his dreams" (Hospitality 8). Partir stages the drama of the rift between the immigrant's European dreamland and the cold welcome that the real Europe reserves to extracommunitarian newcomers with groundless expectations.

Upon Azel's arrival in Barcelona, the romantic rhetoric of the dreamer is abruptly replaced by the arid legal jargon of immigration bureaucracy: "papiers," "passeport," "tonnes de paperasse," "avocat," "contrat de travail" "papers; passport; tons of paperwork; lawyer; employment contract' (Partir 76) seem the new rite of passage "pour avoir la paix" 'to attain peace' (76). To be sure, Azel shares this obsession with paperwork as a road to Europeanness with most characters in the novel, all dazzled by the mirage of the other, better shore. Although Azel's sister, Kenza, takes with her a great deal of her country in the suitcase filled with 
her mother's food specialties, it is her own identity as a Spanish legal resident and Spanish-speaking "épouse fantôme'" 'phantom spouse' (142) of Miguel that allows her to find a regular job as she longed for. More than a nostalgic call back to North Africa, the apparition of Moroccan food on the Spanish territory rather works as a metonymy for the general impulse to cross the Mediterranean frontier and land on the European continent. What accompanies the fragrances of oliveand-lemon chicken, spices, and honey cakes in the suitcase are, not accidentally, Lalla Zohra's immigration forms that Kenza's mother leaves with her daughter, so that they can be processed thanks to her European husband.

Likewise, Siham, who yearns no less than Aziz's family members to migrate to the closest piece of Europe, owes to the affluent and connected El Haj an employment opportunity that can justify her long wait at the Spanish consulate for a visa request. To care for a handicapped girl may not sound like the dream job. Siham is indeed shocked by the difficulties and also haunted by a sort of melodramatic imagination that makes frightening racial and cultural clichés emerge-like kidnapping or sexual abuse by her future Saudi employer. However, hardships and homesickness are not enough for her to yield to the temptation to go back. The chances offered by her four-month European visa are a sufficiently good incentive to put up with the emotional distress of her current job situation in Spain rather than falling prey to the compromises to which women have to stoop in her home country in order to survive-such as becoming a patron's lover or marrying a widower with children, instead of securing economic independence. And if for Mohamed Larbi the much-awaited European visa that discretely takes him to Brussels also marks his fatal entanglement with a Muslim extremism that will ultimately make him lose Europe altogether, in the case of Malika, the European passport materializes only as a makeshift surrogate in her reveries. Her "carnet maquillé en passeport européen" 'notebook disguised as a European passport' (Partir 124) compensates in extremis for the only meager and grotesque piece of Europe Malika can touch in real life-the shrimp of the Dutch company for which she works in Tangier harbor-until, in her final agony, she succeeds in abandoning her Moroccan existence but, tragically, only to be buried, without ever fulfilling her European dream.

However, those characters whose European dream does not die before their actual Mediterranean crossing are not exempt, either, from the perverse coup de grâce that massive bureaucracy and rigorous laws inflict upon the migrant's bovarysm. The newcomer's illusion that naturalization documents can automatically guarantee integration, producing that sense of belonging to and of fulfillment in the adoptive European home, is soon broken. Even when, beyond moral response, European hospitality translates into political measures, compliance with the laws of asylum and with the rights of citizenship does not necessarily bestow Europeanness, as Ben Jelloun himself attests in an interview soon after the release of Partir. His intention with this novel-he declares-was to depict characters who live in Spain "dans une sorte de clandestinité, d'illégalité" 'in a sort of clandestinity, of illegality' ("Rencontre"). Azel and Kenza are no exception, since, as Ben Jelloun observes, despite their regular immigration process, they tricked the system, with Miguel's aid, to obtain legal status, but—it should be added-also because, even after becoming European residents (no matter how), they, as several other characters in the novel like Siham, remain at the margins of Spanish society without the 
consciousness and the concrete opportunities of real participants in European life. There is hence a certain irony in Miguel's triumphant exclamation to Kenza "tu es citoyenne européenne" 'you are a European citizen' (Partir 194) once bureaucracy has done its job. In fact, the burgundy passport with the golden title "European Union" ready for pick-up will accentuate what for Balibar is the tension between "a universalization of the "community of citizens" (We 61) and "the interior exclusions that are its counterpart" (61) whenever the immigrant endowed with rights and dignity also attempts to establish deep social and historical connections in the milieu of his/her naturalization. This "condition of solidarity," Balibar concludes, "is never acquired 'naturally'" (61).

The evolution of Azel's state of mind and personal life is symptomatic of the profound trauma generated by the cleavage between what we may call the migrant's pleasure principle - the easy Europeanization of his dreams-and the reality principle-the concrete social, political, and administrative mechanisms of Euromediterranean relations and of European immigration, laying bare the antinomies of the notion of community (Balibar, We 69) and challenging idealized perspectives on hospitality. Hospitality, we read in Ben Jelloun's essay, "asks for no return" and "can exist only where there is complete disinterestedness" (Hospitality 3). In Partir, however, we soon realize that, even at the basic level of interpersonal relationships connecting Europe with the non-European "stranger," this apparently unconditional generosity is not exempt from the laws of reciprocity. Symbolic of the dealings between their respective nations and continents, the liaison between Azel and Miguel shows that any act of human solidarity is a give-and-take propelled by the compromises and the ulterior motives of both parties. Indeed, no sooner does Azel set his feet on the European soil than he abandons all thoughts of gratefulness to Miguel for granting him the opportunity to cross the Mediterranean. What occupies his reflections, rather, is the conviction that "Miguel ne faisait pas tout ça par pur altruisme" 'Miguel was not doing all that out of sheer altruism' (Partir 76). And, disappointed by the mediocre accommodation he is offered in the luxurious dwelling of his benefactor, so different from "le paradis dont il avait rêvé" 'the heaven he had dreamed of' (77), Azel addresses once again his own country with a letter that, in striking contrast with the enthusiastic and carefree tones of the previous one, immediately highlights the opposition rather than the solidarity between the two nations: "Tu sais, du Maroc on voit l'Espagne, mais la réciproque n'est pas vraie. Les Espagnols ne nous voient pas, ils s'en foutent, ils n'ont que faire de notre pays" 'You know, from Morocco we see Spain, but the opposite is not true. The Spaniards do not see us, they don't give a damn, they have no need of our country' (77).

Dictated by Azel's feeling of being a pawn in the service of Miguel's sexual and emotional satisfaction, the blame on the Spaniards' indifference also brings up Europe's insufficient involvement in the promotion of political, economic, and social change in North Africa both in the period depicted in the novel and at the time of the novel's publication. For instance, the 1995 adoption of the Barcelona Declaration, announcing a partnership between the European Union and several southern and Eastern Mediterranean nations to foster stability, democracy, and free trade in the area, has generated skepticism and even hostility in North African countries against Europe's measures. ${ }^{7}$ Within the Maghreb, Morocco has been a desirable partner for political and economic cooperation, but EU-Moroccan 
relations are still struggling to reach the right degree of political opening in both Moroccan civil society and in its government (Haddadi 167) and to downsize the EU's democratization projects to a more manageable, local scale. Even the EU's most recent step to complete the Euromed dialogue initiated in Barcelona (namely, Sarkozy's 2008 "Union for the Mediterranean" that is supposed to bring together all EU members with various non-EU countries bordering the Mediterranean Sea) has been received with mixed feelings on both sides of the basin-one of the main objections being the urgent need to foster a sense of unity in the people's minds and hearts before forging alliances at the negotiating table.

Precisely the two European countries more directly connected to the context of Partir and to Ben Jelloun's personal experience-Spain and France-play a pivotal role in the Mediterranean both as contributors to joint European initiatives and as independent policy-makers. Hence they have come under greater scrutiny for their approaches to matters of democracy and human rights promotion in the Maghreb, with crucial implications for inter-African and Europe-bound migration. Indicted for the protection of its own interests in North Africa even after it abandoned the Western Sahara in 1976, Spain has gradually changed its foreign policy with the declared aim of developing political dialogue and economic cooperation with the Maghreb. However, the Spanish government's more recent objective of a "dynamic stability'" (López García and De Larramendi 171) in the region has been interpreted as only a partial openness to the democratization of North African countries, acceptable to the extent that it does not compromise Spain's own national objectives. Indeed, precisely because of the many ongoing tensions between Spain and North African countries-with Morocco at the forefront-on strategic matters among which is immigration itself, Spanish aid to those countries continues to be considered inadequate to reach the stated goals. Furthermore, Spain has also been criticized for exploiting its role in the European Union by remitting certain foreign policy measures towards the Maghreb and by influencing them without appearing as the main source of friction with its North African counterparts.

This utilitarian attitude has hurt in particular the fate of the so-called "anchorage" of Morocco to the European Union, a privileged association agreement mainly of an economic nature, which, however, suffers from Spain's slow action on human and political rights. Paradoxically, it is the very proximity of Spain to Morocco that constitutes an obstacle to stronger bilateral relations (Feliu 92). In the years of Moroccan history discussed in Partir, the signs of Spain's political will to develop programs enhancing Moroccan civil society and governance reforms were limited to isolated cases. Spanish nongovernmental agencies have only recently begun to work in Morocco, but not even the confidence in Mohamed VI has sufficed to promote a comprehensive and consistent democratization plan, and to push Spanish interventions beyond mere economic self-interest. Furthermore, in matters of foreign immigration, especially from Morocco, the fact that Spain experienced this phenomenon later than other European nations, after a period of political isolation and a lack of recent colonial history, has generated much public anxiety, harsh political battles and strict legal measures (see López García).

In Ben Jelloun's novel, Abbas-“"sans papiers, sans domicile connu, sans travail" 'without documents, without a known address, without work' (Partir 154), but successfully settled in Spain after a couple of life-threatening clandestine 
crossings and expulsions-echoes the Moroccans' frustration against what are perceived as Spain's incongruous and hypocritical foreign policies and its arrogance towards the Southern Mediterranean shores that, boosted by its membership in the European Union, seem to have rendered Spain insensitive to the lack of wealth and of freedom that it once shared with its North African neighbors:

Je les connais, les Spanioulis, des pauvres qui sont devenus riches et ont oublié qu'ils ont été pauvres, je me souviens, mon père me racontait que les Spanioulis venaient chez nous comme des mendiants (. . .) ils étaient pires que nous (. . .); le pays va vite, l'Europe le tire vers le haut et l'éloigne de nous, (. . .) quatorze malheureux kilomètres nous séparaient, en vérité il y a des milliers de kilomètres entre eux et nous.

I know the petty Spanish, poor people who have become rich and who have forgotten they were poor, I remember, my father would tell me that the Spanish used to come to us like beggars ... they were worse than us ... the country is going fast, Europe pulls it upward and moves it away from us . . fourteen wretched kilometers used to keep us apart, in fact there are thousands of kilometers between us and them. (Partir 155-58)

For their part, the tones of the critique against French policies towards North African countries are not very different from those against Spain, to the point that both countries are often highlighted as the most unwilling EU members to push for human rights policies in Euro-Mediterranean relations (Feliu 95; Daguzan 135-48).

The importance of both political measures and cross-cultural understanding for an effective Euro-Mediterranean partnership-asserted by France and Spain despite their questionable practices-finds an eloquent endorsement in Ben Jelloun's own words, which, although addressing the situation of North Africans in France, are equally appropriate for the Spain depicted in Partir and more and more significant to Europe as a whole. Urging France to rethink the idea of hospitality, Ben Jelloun posits the need to

overhaul our perception of migration as a phenomenon and see it anew in the context of the blatant inequality in development between the North and the South. ... [I]mmigration is neither a bolt from the blue nor a bottomless pit of problems. It is a fact, arising out of the course of history and economic upheaval. ... Schoolchildren should be taught the history of immigration in the same way as they are taught twentieth-century history, because it is part of their country's heritage. You can't fight racism unless you attack ignorance, prejudice and ready-made ideas about immigration. (Hospitality 31-32)

Partir supports this standpoint, yet it also revises it critically. Reflecting Ben Jelloun's blame on his own nation, the novel suggests the need to consider the faults of Moroccans as well, not only as a people, but also taken individually, starting from Azel's lack of gratefulness towards Miguel for facilitating his safe landing in Europe. Azel is granted the option of a Spanish and European legal stay at the cost of major compromises that reduce him, in many ways, to a hostage of Miguel's sexual and emotional satisfaction. Yet, at the same time, Miguel gives in on a number of fronts for the well-being of Azel and his family, even converting to Islam to marry Kenza and to grant her legal residence in Spain. Significantly, however, his 
serious preparation for this religious event that turns him into Mounir does not suffice to secure him the acceptance of the Moroccan Muslim community-an eloquent demonstration that Morocco's compliance with the laws of hospitality can be at times as flawed as that of Spain and Europe: "Même s'il s'est converti à notre religion, il reste un étranger, un chrétien" 'Even if he has converted to our religion, he remains a stranger, a Christian' (Partir 129). Excluded from the language and culture of his "spouse," hence no less Moroccan and Muslim than Kenza is Spanish and European, despite legal paperwork and formal rituals, Miguel-Mounir experiences the same distressing "othering" that affects Azel and all the migrants allured by bovarysm to the other side of the Mediterranean.

Azel's increasing distress for his sexual duplicity, weakening, and confusion caused by his relationship with Miguel is the symptom of a greater ambivalence and crisis common to most allegedly Europeanized immigrants in the novel. Having indeed become, despite his persuasion to the contrary, "un renégat à son identité, et à son sexe" 'a traitor of his identity and of his sex' (Partir 89), Azel feels he has nothing to share any more even with his other compatriots settled in Spain"il se sentait même étranger à leur langue, à leurs manières, à leur monde" 'he even felt like a stranger to their language, their manners, their world' (177). At the same time, however, he cannot find the comfort of a new self, either. Azel's double estrangement, both from his Moroccan roots and from his newly acquired Europeanness, substantiates what Mohamed Larbi and his uncle Sadek had already claimed about the pernicious, alienating hybridity caused by migrancy, often resulting in uneducated and violent children, neither totally European nor truly Moroccan, to whom parents speak "un mauvais arabe truffé de mauvais français" 'a bad Arabic riddled with bad French' (92). And, as Ben Jelloun himself observes in his essay on hospitality, precisely because "they lack any strong consciousness of where they belong" (Hospitality 107), children of North African immigrants to the Old Continent are uncertain about who they are despite their identity card from a European country, and hence "can't help strengthen their community's cultural defenses" (107).

In Partir the destabilizing problem of this eternally "pending" (Hospitality 107) identitarian status erasing even the symbolic and cultural value of the legal document that should certify legal European status is the main source of anguish for all the migrant characters, confined to that marginal, liminal condition that Azel calls "l'arrière-pays de ce pays" (Partir 153) and which, in Alessandro Dal Lago's terms, is the double alienation of "non-persons" (Non-persone). Partir demonstrates that, regardless of circumstances and of the outcome of their Mediterranean crossing, migrants turn into paradoxical nonexisting human beings, because, although their lives look socially and materially analogous to those of the Spanish and European citizens with whom they share the territory, they do not exist either for those very societies or for themselves (Non-persone 207). More radically than in Dal Lago's argument, they are condemned to invisibility by their foreignness even when they are socially and juridically legitimized.

The voice that denounces this painful truth in Ben Jelloun's novel belongs, significantly, to Moha, the doubly ex-centric figure of the madman-philosopherprophet within an already marginal world. Haunted by death, Moha deprecates the Moroccans' facile idealization of departure as the sole remedy for their destitution, and attacks the mirage of Europe and its ideology of discrimination. Against 
the backdrop of a Morocco plagued by a dangerous identity crisis, geographically anchored to the Southern Mediterranean shore but leaning towards its Northern counterpart and contaminated by Eurocentrism, Moha brings back to the foreground the sacredness of Africa's geographical and cultural roots as the main source of safety and redemption. This sacredness, among other things, comes from the solidarity and hospitality that, in the novel, seem to have gone extinct among Moroccans, who, caught in a perverse master-slave dialectical relation, retaliate against other Africans with the same domineering attitude of which they are targets in Europe (Partir 146-48).

It is only towards the end of the novel that the characters-now deeply disenchanted (if not definitely annihilated as in the case of Azel's violent death) by their traumatizing European adventure-understand the painful truth of Moha's oracle. If, after much yearning and toiling, the North African migrant's only emotion towards Europe is the raging desire to spit on its soil, what is left other than "partir" once again, in the illusion of a comforting homecoming? Sadly, however, this will in fact amount to yet another attack of bovarysm-the sheer fantasy of home as a compensatory shelter-in the next stage of this endless, chronic exile from one's self. Once again, Ben Jelloun's own depiction of the migrant's ambivalent status and inner conflicts in his essay on French hospitality comes to mind: "In France he dreams of the country he left behind. In his own country he dreams of France. Between a host country that is hostile and a native land that is indifferent, he humps back and forth a bag full of small possessions and grand illusions" (Hospitality 116).

We are quite far, here, from the "contrapunctal" ("Reflections" 148) awareness that, according to Edward Said, makes exiles experience life in the new environment alongside the vivid memories of the old one, relishing the "unique pleasure" of "acting as if one were at home wherever one happens to be" (148). Rather than enjoying the risky but exciting "plurality of vision" (148) that Said associates with the "nomadic, decentered" (149) exile's existence, or practicing the critical resistance to codified social habits in the shifting cultural and identitarian scenarios of Rosi Braidotti's nomadism (Nomadic 5), the trans-Mediterranean migrants in Ben Jelloun would like but cannot settle in a fixed identity and mode of behavior. They are doomed to exclusion on both shores, simultaneously as the hospes, the upsetting stranger demanding hospitality, and the hostis, the enemy, both on the European territory and back to their own homeland. Neither fully present nor radically absent in either location, the stranger in Partir, we could argue, hence embodies the spectral condition with which Derrida designates a pseudo-materiality undermining the ontological opposition between reality and illusion. In Azel's own words, connoting the arrival of North Africans to the Old Continent and indirectly blaming Europe's neglectful reception of extracommunitarian migrants, "nous surgissons de la mer comme des spectres ou des fantômes" ‘we arise from the sea like specters or phantoms' (Partir 153).

\section{SPECTERS OF EUROPE}

Siham's sudden impulse to "repartir" as soon as she sets foot in Europe (Partir 83) and Soumaya's homesickness after her downfall from spoilt child in a wealthy Moroccan family to servant in a Spanish cafe (106) are just two early symptoms of 
a growing urgency to quit an alienating existence in the Old Continent and cross the Mediterranean once again, back to its Southern shore. The nostalgia and lucid despair of Azel (who ends up as an undocumented and unemployed illegal alien after breaking off with Miguel) and of Kenza, in shambles after Nazim's betrayal shatters the love story of her dreams, are acknowledged by Miguel who, ironically, after fulfilling their European fantasies, also decides to send them back home to save them from the terrifying dark tunnel that Europe has become for them (243).

But significantly, even at the bottom of their abysmal degradation, Azel's and Kenza's deformation of reality is still articulated as a bovarystic delusion, further widening the gap between individual desires and actual conditions. Under the impulse of "être quelqu'un d'autre" 'being someone else' (Partir 247) one more time, despite wrong choices and broken reveries, Azel, now a secret informer for the Spanish police fighting against the terrorism that threatens Europe, still dreams of returning to Morocco like a hero and of appearing on TV "comme le bon musulman grâce à qui une tentative d'attentat aurait été déjouée" 'like the good Muslim thanks to whom an attack would be thwarted' (248). And the resiliently romantic Kenza, waiting to "rencontrer l'amour, le vrai, le grand, l'amour sincère, l'amour bouleversant (. . .) que les films et les romans qu'elle avait vus ou lus et aimés décrivaient si bien" 'encounter love, the true, great, sincere love, the overwhelming love (. . .) that the films and novels she had seen or read and loved described so well' (250), still hopes to find in Europe "ce qui la rendrait folle de Bonheur" 'that which would drive her crazy with joy' (250), just as Emma Bovary, infatuated with tales of passion, insistently looks for the frissons of sweeping emotions beyond her "bastard" town of Yonville. Yet, with the same facile dreamy enthusiasm, on the death of the despotic King Hassan II, Kenza projects back onto her native country the chance of a better life.

Unfortunately, however, the actual return in the novel takes on the fictitious, mythical quality that Ben Jelloun discusses in his essay on hospitality (Hospitality 119-26), showing how most times the unrealistic prospect of going back to one's own country entails integration problems as remarkable as those emerging on the European territory precisely due to the gap between expectations and concrete circumstances. At the end of the novel, the reappearance of Flaubert-the narrator's friend who had opened Partir with a blurring of realistic and fictional detailsreinforces the ambivalence and complexity of the scenario. Indeed, although Flaubert denies the link with the literary world, he not only personifies literature but even introduces, in his turn, other self-conscious references to literary figures and their imaginary constructions-from Apollinaire (supposedly not the French poet but rather a cousin of his who made money as an illegal immigrant in France and then went back to Cameroon) to the insinuation that Azel could be a writer's name. Mingling with the aura of authenticity of the migrants' own narratives, those fictional echoes act as a prelude to the postmodern conclusion of the novel, where self-conscious literariness brings to the foreground the foreigner's hybrid status, suspended between home and abroad, departure and return, Africa and Europe.

Indeed, as more explicitly literary figures show up-“Émilzola, bibliothécaire à Douala" 'Émilzola, librarian in Douala' (Partir 263), "un gros bonhomme qui prétend s'appeler M. Panza" 'a fat fellow who claims his name is Mr. Panza' (264), "Don Quichotte, du moins celui-ci prétend s'appeler ainsi" ‘Don Quixote, at least this guy claims this is his name' (265) — and the scenes become more 
visionary and virtual, Flaubert's idea of "partir pour revenir" 'leaving in order to come back' (219) is magnified in the last chapter, "Revenir," which alludes to but does not conclude with a simple turnabout. Rather, the "vent du retour" 'wind of the way back' (255) that makes the migrants dream of freedom back to their roots, in fact confines them to the extreme liminal condition: all those who have not found a place either in their Moroccan motherland or in what they elected as their European home will continue to drift on the Mediterranean waves.

The backdrop for this fluid condition is, not accidentally, a boat, whose symptomatic name Toutia does not simply evoke the protean nature of the sea but also, more specifically, reinstates the ambivalence that in the first pages of the novel had connoted the sea as vox media, as the simultaneously benign and fatal mediator between the two shores. No less than the images of the dismal cemetery and of the devouring spider-the lethal side of the sea to which Tangier's migrants entrust nonetheless to quench their thirst for Europe-the boat Toutia that promises survival through repatriation radically separates them from the object of desire without the compensatory consolation of a sheltering homeland. Aboard this purveyor of both life and death, passengers embark on a final yet endless journey on the threshold of those two states, as spectral creatures carried once again at sea by two Charon-like ferrymen of Hades - the boat captain and his assistant "Toutia-la-Sublime" (Partir 256) — until the hypothetical trespass "vers d'autres cieux" 'towards other skies (257) puts an end to their painful errance.

In this hallucinatory, ambivalent space, the condition of Ben Jelloun's migrants magnifies the question that for Derrida challenges the very possibility of hospitality (Of Hospitality 3). Coming from abroad, the foreigner is at once a "being in question" (3), scrutinized and challenged by his host, and that unexpected, alien presence that, in its turn, threatens its host's integrity. Authentic, absolute hospitality, which would require unconditional acceptance of the guest without any prior knowledge of his identity, origin and legal status, clashes with the juridical protocol of hospitality as regulated by norms restricting the encounter with otherness. In the collision of these two incompatible injunctions Derrida locates the aporia of hospitality itself (77-81), an antinomy that, through conditions like that of the exiles in Partir, undoes the duality of self and other. The migrants aboard Toutia recall their spectrality to their living hosts who made it impossible for them to enjoy complete inclusion in their European home. Returning as revenants, neither present nor absent, neither fully visible (as objects of perception, recognition and juridical representation) nor totally invisible, they trouble the closure of that cultural, social and political space to which they cannot belong, on either shore.

If we accept that the question of place is the foundation of culture (and it is, all the more reason, crucial to the configuration of a specifically European culture beyond the boundaries of the nation), the double exile to which Ben Jelloun's migrants are doomed undermines what for Derrida is the utopian political dimension of the foreigner's question. The placelessness of the exile's dwelling, at once native and in transit, reminds the host that the subject is by definition a guest, never at home, always on the threshold, and it is the uncovering of this disturbing estranging dimension ingrained in the self and in its culture that advances what for Derrida is "the possibility of the human 'city'" (Of Hospitality 74), that is, a redemptive political space that prevents the fixity of sovereign power and guarantees the authentic ethical dimension thanks to the troubling otherness of 
the guest that turns up. Hospitality is ethos itself, because, as Derrida claims, it pertains to the ways of relating to oneself and to the other, "to others as our own or as foreigners" (Cosmopolitanism 17). More skeptically, however, Ben Jelloun's novel offers only a parody of such a utopian European political space. The ship that hosts the would-be Europeans, carrying them away from their promised land as Europe's "others," confines them to a restricted area that, instead of relating self and other as in the ideal hospitable, ethical place, represents a grotesque reversed double of a city of refuge. Instead of offering a free zone where exiles, refugees, and immigrants are welcome and protected in view of their future naturalization, Toutia rather generates an ironic "imagined community" (Anderson) made of all the failed and displaced dreamers of Europe, cast off as on a ship of fools without the consolation of a comeback to their own roots.

As the narrative voice confirms in Partir by declaring, on behalf of all the boat passengers against the backdrop of the sea as cemetery, "J'ai perdu mon nom et je n'ai plus de visage ... . je ne sais pas qui je suis" 'I have lost my name and I don't have a face any more . . . I don't know who I am' (257), Ben Jelloun's migrants now appear as "neither substance, nor essence, nor existence" (Derrida, Specters xvii), and, precisely with their status as "non-objects," "non-present presents" (Specters 5), they call for justice in contexts where it is no longer or not yet there. The phantoms of Partir, no longer Moroccan but not entirely (and never) fully Spanish and European, exhibit their "disjunction" and "inadequation to self" (Specters xix) to highlight the hiatus between legal and human justice in matters of hospitality between Africa and Europe. The few kilometers that keep the two continents apart and yet fuel the migrants' bovarysm effectively delineate the contours of that "geography of proximity" (Of Hospitality 2) responsible, according to Derrida, for the specter's disturbing closeness to its host. The alien yet neighboring guests that inhabit the domesticity of Europe in Partir hence substantiate Derrida's reinterpretation of the question of Europe as the "question of spirit" (Specters 224n3), where "spirit" stands as much for European thought and consciousness as for the "specter" that marks and mars them, turning "ontology" (the reassuring thought of a self-sufficient, self-identical being) into what Derrida defines as "hauntology" (Specters 10), the more unsettling logic of haunting associated with a paradoxical state of neither being nor not being.

The ambivalence of the ghost is inscribed into Toutia itself, a boat which, at once "familier" 'familiar' and "étrange" 'strange' (Partir 257), evokes the uncanniness of the Freudian return of the repressed and makes the migrant phantoms return as both Europe's and Africa's repressed alter ego. Furthermore, the haunting proximity of the spectral passengers to both Mediterranean shores goes hand in hand with the blurred, liminal identity of characters transported on a boat that is perhaps "juste une maquette, un trompe l'oeil, une simple image projetée sur l'eau" 'just a mock-up, a trompe-l'oeil, a simple image projected on the water' (257), and themselves suspended between reality and fiction. In Ben Jelloun's concluding chapter, indeed, the absolute dissymmetry of the spectral moment that for Derrida no longer belongs to time in the sense of a sequence of "modalized presents" (Specters xix) coincides with the hyperreal atmosphere in which characters of the literary past mingle with the contemporary protagonists of Partir. Hence, the beautiful Soumaya, who covers her face with a veil hiding the devastating scars of her car accident on the Spanish territory but also symbolizing the disfiguration that the 
entire European experience left on her, appears next to Flaubert, who, having fled from the "real" world, has found "un emploi fictif dans une fiction, (. . .) se balade dans des livres, se couche dans des pages que des femmes parfumées ouvrent délicatement pour les lire" 'illusory employment in a fiction ... wanders in books, lies down on pages that sweet-smelling women gently open and read' (263), hinting that the boat itself might be nothing more than "une fiction, un roman flottant sur les eaux" 'a fiction, a novel floating in the water' (261). At once a compensation for the tragic failures in their migrant lives and an additional exile from reality that keeps characters apart from both their motherland and their elected European home, Ben Jelloun's final blend of realism and fantasy challenges the cold logic of self-identity and reopens the question of hospitality from the place of the foreigner as being in question (Of Hospitality 3-5), by letting speak "les voix de l'étranger qui nous habite " the voices of the stranger who lives within ourselves' (Partir 266). Significantly, in the final pilgrimage of these doubly estranged creatures, the last "personne, ou plutôt (. . .) personnage" 'person, or rather (. . .) character' (265) who boards Toutia before it sets sail towards nowhere is Moha, here connoted as the "immigré anonyme' 'anonymous immigrant (266), that is, the representative of all those dislocated creatures, a sort of unknown soldier symbolizing the suffering of the entire migrant community and the annihilation of their collective European dream.

On the one hand, therefore, the self-conscious literary dimension of those pivotal scenes where the novel's downtrodden characters settle in their makeshift, surrogate homeland offered by Toutia seems to reinforce Derrida's claim that hospitality can only coincide with a poetic act (Of Hospitality 2; emphasis added), an act of invention and creativity that coins a new logic and a new language through which the encounter with the foreigner can transcend political and philosophical constraints and juridical impasses. On the other hand, however, this welcoming displacement to the realm of imagination ironically reinstates the enduring, utopian power of wish fulfillment in a creative elsewhere as the last attempt to compensate for a Euro-Mediterranean reality in which unconditional hospitality has no place. In the bovarystic framework of Partir, then, literature can be said to play a more problematic role in the migrant's experience than the one emerging from Ben Jelloun's essay on hospitality. The essay posits the need for a form of intellectual hospitality that complements the foreigners' social integration by contributing to the receiving culture not only with labor but also with "something of their imagination" (Hospitality 129). In Partir, however, imagination does not free the migrants from fear and silence, nor does it open them up to the society of their adopted country or to their birthland. Rather, it marginalizes them. The specters of Europe here remain "aesthetes of silence" (Hospitality 127-30) while the narrator brings literary imagination to the foreground on their behalf but only as a critical stance on the promises and snares of Europeanness without boundaries and of a safe return home.

Interestingly, the ambivalent perspective of the novel does not blur the distinction between powerful, stable guests and powerless, nomadic hosts as in the fluid scenario on hospitality in the postcolonial contexts examined, for instance, by Mireille Rosello (see Postcolonial). Likewise, the ship in motion across continental spaces in the final chapter does not delineate, as in Paul Gilroy, the "rhizomorphic, fractal structure of the transcultural" (Black 4) as a global and fragmented space 
where ethnic constraints and national specificities cease to matter. Rather, Partir shows us that stories of individual races, cultures and nations still have much to tell, and that, despite official speeches and eroded borders, barriers persist around Fortress Europe-barriers that Europeans are not ready to demolish, but, at the same time, also barriers that non-Europeans are not always able to perceive or equipped to overcome. With his latest novel, therefore, Ben Jelloun also casts a shadow over the hope expressed by Azouz Begag for Europe as a place to be conquered by new generations of Maghrebian immigrants, one that not only abolishes real and imaginary frontiers in view of the proverbial circulation of people, goods, and ideas promoted by the Schengen Convention, but also prefigures "une autre promesse, un autre rêve, l'ouverture d'un autre espace: la communauté méditerranéenne" 'another promise, another dream, the opening of another space: the Mediterranean community'(Écarts 118). For Begag, South Mediterranean migrants are "éclaireurs" (118), pioneers whose imaginary site will eventually turn into the real Euro-Mediterranean supranational space. Partir, however, moderates our enthusiasm for the prospect of this geocultural redistribution, which in its pages is still a chimera.

Ben Jelloun's identitarian écarts do not represent, yet, optimistic deviations and differences able to infuse new blood into the cultural veins of the Old Continent. Rather, they stand for rejected residues, spectral traces beckoning from "le froid de l'exil" (Partir 256), the deadly cold of a double outlandishness from both Mediterranean shores. Of the light in the etymology of Begag's intrepid "éclaireurs" (Écarts 118) at the end of Partir we find only the feeble "petite lumière" "little light' (Partir 267) of the human soul that propels the migrants' drifting without any certainties other than the ambiguity of a "peut-être" 'perhaps' (267), able to lead as much to security in the home of the "other" as to demise because of the "other."

\section{NOTES}

1. All English translations are mine unless otherwise stated. No English translation of Ben Jelloun's Partir was available when this article was submitted for publication (August 2008).

2. Just a sample quotation from Madame Bovary, among the many that can resonate in Azel's own reveries: "Emma (. . .) se réveillait en d'autres rêves. Au galop de quatre chevaux, elle était emportée depuis huit jours vers un pays nouveau, d'où ils ne reviendraient plus" (Deuxième partie, ch. 12 : 223) / "Emma ... lay awake, dreaming other dreams. For a week now, four galloping horses had been speeding her towards a new land, from which they'd never return" (Madame Bovary. Trans. M. Mauldon 174).

3. The mythical ferryman of the Greek underworld, carrying the souls of the deceased across the river Acheron dividing the world of the living from that of the dead.

4. Ben Jelloun makes these claims also independently of the different events that shaped France's relationship with Algeria with respect to Tunisia and Morocco, for instance. He maintains that North Africans "all feel the same disappointment" (Hospitality 71) confronted with France's reception of them, for "there isn't the same sense or quality of hospitality on both sides of the Mediterranean" (71).

5. "Cher pays, (...) Je ne te quitte pas définitivement, tu me prêtes seulement aux Espagnols, nos voisins, nos amis. Nous les connaissons bien, longtemps ils ont été aussi pauvres que nous, et puis un jour (. . . la démocratie est arrivée, suivie de la prospérité et de la liberté” ‘Dear country ... I am not quitting you for good, you are only lending 
me to the Spaniards, our neighbors, our friends. We know them well, for a long time they have been as poor as we, and then one day ... democracy arrived, followed by prosperity and freedom (Partir 73-74).

6. Beyond specific political obstacles, certain economic measures, such as privatization and free trade, mandated by Europe in Mediterranean non-EU countries have turned out to be advantageous to a small portion of the population, while worrisome consequences of those measures, such as unemployment and price increases, affected society at large. Democratization and human rights issues have proven an even shakier ground, because of an increasing perception, across the Mediterranean, of a European strategic political design aimed at manipulating and subverting regimes for Europe's own "imperialistic" goals more than for the benefit of its own Mediterranean partners (see Chourou; Youngs).

\section{WORKS CITED}

Anderson, Benedict. Imagined Communities. London: Verso, 1989. Print.

Balibar, Étienne. We the People of Europe? Trans. James Swenson. Princeton: Princeton UP, 2004. Print.

Begag, Azouz, and Abdellatif Chaouite. Écarts d'identité. Paris: Seuil, 1990. Print.

Ben Jelloun, Tahar. French Hospitality. Racism and North African Immigrants. Trans. Barbara Bray. New York: Columbia UP, 1999. Print.

- Partir. Paris: Gallimard, 2006. Print.

. "Rencontre avec Ben Jelloun, à l'occasion de la parution de Partir (2006).” Web. 10 Sept. 2007. <http://www.gallimard.fr/catalog/Entretiens/01057583.htm>.

Braidotti, Rosi. Nomadic Subjects. New York: Columbia UP, 1994. Print.

Chourou, Bechir. “The Challenge of Democracy in North Africa." Gillespie and Youngs 17-39. Print.

Daguzan, Jean-François. "France, Democratization and North Africa." Gillespie and Youngs 135-48. Print.

Dal Lago, Alessandro. Non-persone. L'esclusione dei migranti in una società globale. Milan: Feltrinelli, 1999. Print.

Derrida, Jacques. Of Hospitality. Trans. Rachel Bowlby. Stanford: Stanford UP, 2000. Print.

-. On Cosmopolitanism and Forgiveness. Trans. Mark Dooley and Michael Hughes. London: Routledge, 2001. Print.

—. Specters of Marx. Trans. Peggy Kamuf. New York: Routledge, 1994. Print.

Fallaci. Oriana. The Force of Reason. New York: Rizzoli International, 2006. Print.

Feliu, Laura. "A Two-Level Game: Spain and the Promotion of Democracy and Human Rights in Morocco." Euro-Mediterranean Relations after September 11. Ed. Annette Jünemann. London: Frank Cass, 2004. 90-111. Print.

Ferguson, Niall. “Eurabia?” New York Times 4 Apr. 2004, sect.6: 13. Print.

Flaubert, Gustave. Madame Bovary Paris: Flammarion, 1979. Print. Madame Bovary. Trans. Margaret Mauldon. Oxford: Oxford UP, 2004. Print.

Garwood, Duncan, et al. Mediterranean Europe. London: Lonely Planet, 2007. Print.

Gaultier, Jules de. Le Bovarysme. Paris: Mercure de France, 1902. Print.

Gillespie, Richard, and Richard Youngs. The European Union and Democracy Promotion: The Case of North Africa. London: Frank Cass, 2002. Print. 
Gilroy, Paul. The Black Atlantic: Modernity and Double Consciousness. Cambridge, MA: Harvard UP, 1993. Print.

Glissant, Édouard. Caribbean Discourse. Selected Essays. Trans. J. Michael Dash. Charlottesville: UP of Virginia, 1989. Print.

Gnisci, Armando. Creolizzare l'Europa. Letteratura e migrazione. Rome: Meltemi, 2003. Print.

Gold, Peter. Europe or Africa? A Contemporary Study of the Spanish North African Enclaves of Ceuta and Melilla. Liverpool: Liverpool UP, 2000. Print.

Haddadi, Said. "Two Cheers for Whom? The European Union and Democratization in Morocco." Gillespie and Youngs 149-69. Print.

López García, Bernabé. “Foreign Immigration Comes to Spain: The Case of the Moroccans." New European Identity and Citizenship. Ed. Rémy Leveau, Khadija MohsenFinan and Catherine Wihtol de Wenden. London: Ashgate, 2002. 49-68. Print.

López, García Bernabé, and Miguel Hernando De Larramendi. "Spain and North Africa: Towards a 'Dynamic Stability'." Gillespie and Youngs 170-91. Print.

Matvejević, Predrag. La Méditerranée et l'Europe. Paris: Stock, 1998. Print.

Rosello, Mireille. Postcolonial Hospitality. The Immigrant as Quest. Stanford: Stanford UP, 2001. Print.

Said, Edward. "Reflections on Exile." Altogether Elsewhere. Ed. Marc Robinson. San Diego: Harcourt Brace, 1994. 137-49. Print.

Youngs, Richard. "The European Union and Democracy Promotion in the Mediterranean: A New or Disingenuous Strategy?" Gillespie and Youngs 40-62. Print. 